\title{
ISIS and the Shift in Terrorism Movement in Indonesia (2014-2018)
}

\author{
Masmuhah $^{1}$, Yon Machmudi ${ }^{2}$, Muhammad Syauqillah ${ }^{3}$ \\ $\left\{{ }^{1}\right.$ masmuhahoecha@hotmail.com, ${ }^{2}$ machmudi@ui.ac.id, ${ }^{3}$ muhamadsyauqillah@ui.ac.id $\}$ \\ ${ }^{1,2,3}$ School of Strategic and Global Studies, Universitas Indonesia, Indonesia
}

\begin{abstract}
The diminishing power of ISIS in Iraq and Syria does not necessarily reduce the intensity of global terrorist. Instead, it poses another threat to other countries with the return of the ISIS militant FTFs who will act in their respective countries. Acts of terrorism in Indonesia since 2014-2018 have been heavily influenced by organizations affiliated with ISIS or ISIS sympathizers. Despite being relatively smaller in terms of scale and casualties, the act of terrorism is demanding and intense. In this period, acts of terror differed from the previous period, both in terms of targets, patterns of movement, motivation, and the actors involved. Therefore, the aim of this research is to find out whether there has been a shift in orientation of terrorism movement in Indonesia in 20142018. The theory used is The Lone Wolf Terrorism. This research is explanative with observation method, interview and field documentation on former terrorist used as primary data, supported by secondary data in the form of literature study. The results obtained from this study indicate that there has been a shift in the orientation of terrorism movement in Indonesia in a number of aspects, namely the shifting pattern of movement due to the emergence of lone wolf terrorism, the shift in motivation due to the concept of takfiri and the purpose of establishment Daulah Islamiyah by ISIS, shift in recruitment method from conventional to modern as well as actors involving teenagers, women and children.
\end{abstract}

Keywords: ISIS, Terrorism Movement, Lone Wolf Terrorism

\section{INTRODUCTION}

Since its foundation, the core purpose of ISIS's strategy is the creation and expansion of the Islamic caliphate. While Syria and Iraq remain the ideological heart of ISIS, its leaders seek enlargement of their Caliphate to Africa, the Middle East, and Asia. Abu Bakar Al Baghdadi's declaration is certainly one of the factors of how the "promises" of the Islamic state and the Islamic Caliphate in Syria and Iraq drew the attention of individuals and groups of jihadists all over the world. By mid 2015, more than 30,000 jihadist combatants from around 90 foreign countries came to Syria and Iraq, including a thousand personnels from 
Southeast Asia. ISIS experienced an initial spike in 2014 and 2015 by seizing territory in Iraq and Syria, then expanding to Libya, Egypt, Afghanistan and Nigeria by co-opting local groups. Yet, the group's control over the territory and population then declined as it faced resistance from government forces and non-state armed groups in all sections. The strength of ISIS has diminished since Russian forces attacked the ISIS oil field, ISIS's biggest source of revenue. In addition, many members of the group defected due to cuts in income and not fed. The supply of weapons was declining so that they were defeated in the war. At its peak, ISIS's territory shrank as it was recaptured by Iraqi forces in June 2017. (Waid, 2017)

Without territory, ISIS may have a more difficult time recruiting and indoctrinating additional foreign fighters. Many of the thousands of skilled foreigners will try to get back home, and some may try to attack there. The loss of the core caliphate may also cause some outermost provinces to divert their allegiance, perhaps to al-Qaeda, or to continue operating independently. ISIS's strategy to open the door of foreign mujahidin from various countries succeeded in raising ISIS from the number of soldiers and sympathizers. ISIS became the new magnet of the global jihad agenda, with a campaign call for jihad in the enforcement of Daulah Islamiyah. Since its declaration since 29 June 2014, the establishment of ISIS has triggered more than 140 terrorist attacks in 29 countries other than Iraq and Syria, such as Tunisia, Turkey, France, Egypt, Lebanon, Indonesia and others. (Reuters, 2016)

As a country with the largest Muslim majority, Indonesia is also a fertile ground for the growth of terrorism based on religion. In the period 2000-2005, acts of terrorism weredominated by Jemaah Islamiyah in the form of attacks, large-scale bomb blasts attacked the symbol of foreign imperialism. Twenty-two acts of terror were recorded, with 289 deaths and 834 people injured. From 2006 to 2010, acts of terrorism decreased after the arrest and the death of the leaders of Jamaah Islamiyah. Terrorist groups moved in small groups (selfjihadists). Three acts of terror were recorded, with 9 deaths and 40 people were killed. From 2011 through 2018, terrorist acts were committed by jihadist cells. Types of terror took the form of shootings, murders and bomb explosions. The emergence of differences in understanding the term takfiri and the presence of ISIS in 2014 resulted in the split of Islamic group movements in Indonesia.

The development of the ISIS-affiliated terrorist movement in Indonesia has been happening since the establishment of the Katibah Nusantara Lid Daulah Islamiyah on 26 September 2014 by Southeast Asian combatants of around 500-700 from Indonesia, 200 from Malaysia, the Philippines and Singapore. Katibah Nusantara provides a powerful influence through the publication of online media, blogging, youtube and social media for the movement and terrorism attacks in Southeast Asia. Bahrun Naim, one of the KN commanders, routinely publishes manuals for making bombs, city guerrilla attacks, manuals of biological and chemical weapons, hacking, propaganda and recruitment strategies, to more effective tactical attacks (Sholeh, 2017). In this paper, we will discuss the shift of terrorism movement in Indonesia from the 2000-2013 period which is mostly driven by JI Islamiyah, and the second period terrorism movement from 2014-2018 inspired by ISIS.

\section{SHIFT IN THE TERRORISM MOVEMENT IN INDONESIA (2014- 2018)}

\subsection{Shift in Movement Pattern}

Muhammad Subhan (2016) found that there has been a shift in orientation of the terrorist movement in Indonesia in the form of lone wolf terrorism and the spread of takfiri that divides 
terror groups in Indonesia. The shift in question is the beginning of abandonment tanzhim or organization as a container movement with the start of the emergence of individual terrorism or Lone Wolf Terrorism (Subhan, 2016).

According to Ramon Spaiij, the characteristics of Lone-wolf Terrorism, among others, is that it is done by individuals, for instance actions such as Mapolresta Surakarta bombs (2016). Cicendo Bandung pot bomb (2017), suicide bombing in Kampung Melayu (2017), as well as stabbing of police officers in several districts were done by individuals. The next characteristic is that the modus operandi is understood and regulated by individuals without any command. Some examples of this include acts of terrorism that occurred in Cikokol, Tangerang, Banten on 20 October 2016. At that time, three police officers on duty at Pos Lantas Jalan Perintis Kemerdekaan, Cikokol were suddenly attacked using sharp weapons by unknown persons (later known perpetrators named Sultan Azianzah). During the assault, the 22-year-old man brought a knife and two pipe bombs. However, it was later learned that the perpetrators belonged to the network of Jamaah Anshor Daulah Khilafah Nusantara (JAKDN) group led by Aman Abdurrahman. This means that although the Sultan was listed as a member of JADKN, his actions were done individually (Aziz, 2017). In addition, there are plans to attack members of mako brimob by Dita Siska Millenia and Siska Nur Azizah on the basis of their own initiative because of their ideological belief.

Compared to JI's previous period of terrorism which claimed 289 deaths and 834 injuries, Terrorism Watcher Indonesia, Sidney Jones added that terrorist acts in Indonesia since 2009 experienced a change to low tech. The perpetrators did not use sophisticated weapons in the acts of terror. For example, at the attack of North Sumatra Police that killed Aiptu M Sigalinging, as well as stabbing in Brimob Mosque Falatehan Kebayoran Baru, the perpetrator only used a kitchen knife. The second characteristic is low competence; the actors of terror are not trained professionally as combatants. As Dita Siska Millenia and Siska Nur Azizah were arrested by police for allegedly committing stabbings to members of Brimob in Mako Brimob, these two women lacked martial arts skills and weapons control.

The third character is low casuality, the act of terror only killing a few victims, mostly suicide bomber, such as bomb Kampung Melayu, Panic Cicendo bomb, bomb in tower Wonocolo Sidoarjo, and suicide bombing at Polrestabes Surabaya. The largest number of victims was found after the bombings in the Immaculate Sacred Church of St. Mary, the Pantekosta Church of Arjuna Street, the GKI on Jalan Diponegoro Surabaya, where 13 people were killed. If compared with Bali bomb victims that reached 202 people in one attack, this action is still small in scale. According to Jones, however, law enforement officers should stay vigilant if in the future, the Foreign terrorist Fighters from Indonesia come back with greater capability (Jones, 2015).

Lone wolf terrorism or individual terrorism has become one of the most important trends in terrorism today. This is triggered since September 2014, the call of Abu Muhammad alAdnani, an ISIS official spokesman urging followers, sympathizers and Muslims living in western countries with a call

"If you can kill a disbelieving American or European - especially the spiteful and filthy French - or an Australian, or a Canadian, or any other disbeliever from the disbelievers waging war, including the citizens of the countries that entered into a coalition against the Islamic State, then rely upon Allah, and kill him in any manner or way, however it may be, Smash his head with a rock, or slaughter him with a knife, or run him over with your car, or throw him down from a high place, or choke him, or poison him" (independent.co.uk)

The perpetrators of terror may abandon conventional attack models such as bombs and replace them with other, easier methods. This referes to the fatwa of Sheikh Muhammad Al 
Adnani, which mentions that every member of the attack with weapons owned. This shift resulted in terrorist acts occurring in Indonesia being sporadic, unclear, and different from the previous period in terms of the number and intensity of terror attacks, modus operandi, targets of acts of terror, and perpetrators involved in the terrorist movement.

\subsection{Shift in Motivation}

The ideological foundation is very influential on the motivation of the perpetrators of terror. Al-Qaeda's top leader, Aiman Al-Zawahiri has stated that Al Qaeda has no connection with ISIS because it is a mission to turn from the mission of the struggle by creating sectarian war in Iraq and Syria and the use of violent acts. Basically, ISIS still adheres to al-Qaeda ideology; despite its tactical differences about the stages of struggle and substantive differences regarding personal leadership, Al-Qaeda and ISIS still share the same strategic objectives. Since June 2014, Al-baghdadi demonstrates ISIS's move to take advantage of the territory. Using the diction "Caliph", ISIS intends to exploit the religious, historical, and ideological connotations of a word, in order to impress the resurrection of the caliphal government in the early years of Islam (Nuruzzaman, 2018).

The ISIS ideological belief that officially declared an Islamic state at its founding made terrorist organizations in Indonesia split into pro-ISIS and anti-ISIS groups. Jamaah Islamiyah (JI), formerly affiliated to Al-Qaeda, is divided into a pro-ISIS group, Jamaah Ansharut Tauhid (JAT) led by Abu Bakar Ba'asyir to Abu Bakar Al Baghdadi. Others set up a new antiISIS organization called Jamaah Ansharut Syariah (JAS) led by Abdurahim Ba'asyir. The split in JAT is very strong, and they hate Aman Abdurahman who is regarded as the one who influenced Abu Bakar Ba'asyir to join and bai'at to ISIS.

Until the middle of March 2014, support groups ISIS/IS in Indonesia consist of Jama'ah Tawhid wal Jihad (JTJ), Jama'ah Anshorut Tawhid (JAT) leader Abu Bakar Ba'asyir, Eastern Indonesia Mujahideen (MIT) Director Santoso alias Abu Wardah, remnants of Western Indonesia Mujahideen (MIB) Director Bachrum Shah/Abu Roban, and the Muhajirun which was a splinter from the Hizb-ut Tahrir incorporated in Forum Islamic Sharia Activists (Faction). These groups together founded the Jamaat Ansar Al-Daulah, with Marwan or Abu Musa as temporary leader while waiting for Abdurrahman to be released from Nusakambangan (Nuruzzaman, 2018).

On a regional level, Bashir and Aman have a strategic role for the development of the ideology of ISIS in Southeast Asia. Daulah Islam Malizia (DMI), one of the cells of ISIS in Malaysia cooperated with Kumpulan Arakan Daulah Islamiyyah aim to establish an Islamic State in Southeast Asia (El-Muhammady, 2016:111). In addition, there are a number of principles among jihadi salafi, which are pretty extreme and believed by the majority of supporters of ISIS. Religious doctrine has 5 principles in their religious beliefs, as follows: First, Jihad in the way of Allah (jihad fi sabilillah) is fardu 'ain (obligation of each individual) as acts of worship such as salat, Hajj and fasting. Implementation requires the presence of offensive jihad to certain authorities such as the Caliphate in order to gain new territory, then seizing the territory to enforce the Caliphate is an obligation such as that occurred in Marawi, Philippines.

The second is takfir or takfiri. Takfir determines the position of the muslim community and the members, as the consequences of takfir is giving the conceptualization of who is not a believer or infidel. It is a mechanism for issuing different Muslims with them and protect the Muslims along with them. From the concept of takfir is a takfiri appears to punish infidels and other Muslims that do not agree with them. This is the reason why many attacks of terrorism 
lately targeted civil society and government apparatus both police or national army. Government/police apparatus are seen as kafir harbi by them for capturing and enforcing the law over the terrorists and certainly having wronged their group. Defender of the ideology that is not based on ISIS version of tawheed is called thagut.

Next up is the principle of al wala' wal baro'. Wala' here is being close to the Muslims by loving, helping and protecting them for their enemies and resides with them. While the baro' means disconnecting from ties with unbelievers, so no longer loving them. The fourth is the concept of tawheed. Among salafi, tawheed consists of three parts: tauhid rububiyyah, tauhid uluhiyyah, tauhid asma' wa sifat. Salafi jihadi stated that fighting is the only way to realize unity in particular practical components, namely tawheed uluhiyyah. The fifth is hakimiyyah. This principle states that the sovereignty of the political system and the rule of life of the country is simply the desire of God. Enforcement of the sovereignty of God in the political system, not only will secure the rights of God, but will also provide a temporal empowerment because this is the phase where the message of the Prophet Muhammad is transformed and transmitted on a scale larger than the previous stage (Nuruzzaman, 2018).

The principles stated above were not so strong in previous terrorism movement, namely the Jemaah Islamiyah. The difference in motivation movement of old and new terrorism is also asserted by Ali Imran, a character who gave the response of Jemaah Islamiyah linked Malay Kampong Bomb claimed by ISIS,

"I have no loyalty to ISIS. The difference between Jamaah Islamiyah and ISIS is the difference of aqidah, JI has no takfiri aqidah or tahlili dam (easy to spill human blood). From the target side, JI targeted the connection with the current conflict, JI attacked the Philippine Ambassador in Jakarta, because at that time we were fighting with Mujahidin Moro in the Philippines. Christmas Church bombings of 2000 in several cities, due to religious unrest in Poso. The 2001 Atrium Senen Bomb also linked to the Ambon and Poso conflicts because the target was pastors who wanted to meet at Atrium Senen. The Bali Bombing was due to the American bombing in Afghanistan, so we bombed foreign tourists at the Bali Club, which is mostly American citizens and allies. The action was continued by Dr. Azhari and Nurdin M. Top. JI did not attack the police, our faith is ahlussunnah wal jamaah, we do not justify the blood of fellow Muslims. JI is not attacking thogut, not because we cannot, but we do not believe that."

This difference of ideas and ideology ultimately also affect the motivation, movement pattern, and target of terrorism movement that occurred since 2014-2018. If the previous period of terrorist acts dominated by Jemaah Islamiyah were attacks, large-scale bomb blasts attacking the symbols of foreign imperialism, in recent years the change in targeted terror targets has been transformed into civil society, government officials, both police and national troops (2016), Banyumas (2018), Mako Brimob riot (2018), Police shootings in Tuban (2017), police shootings in Tuban (2016), Surakarta (2016), Banyumas (2017), West Sumatra (2017), to the stabbing in Brimob Kebayoran (2017).

Bomb attacks and Sarinah Thamrin in 2016 was one of the actions that received a strong influence from the online post of the Commander of the perpetrators. They Bahrun Naim and Aman Abdurrahman, two figures of ISIS Indonesia that affected the actors in carrying out terrorism acts. The perpetrators were affected by Jihad mindset. The elite jihadist and terrorists pose a powerful influence over the development and movement of terrorists, who follow instructions published through online media and social media (Sholeh, 2017). In the case of other individual terrorism since 2014-2018, many sympathisers also found to carry out the action on the basis of their own initiative. 


\subsection{Shift in Recruitment Method}

There are two changes that occur on the methods of recruitment of Jemaah Islamiyah terrorism movement and ISIS. The first was on recruitment and media. The previous period of recruitment was offline-centric on islamic study activities, as well as maximizing Afghanistan alumni network. Then in this period makes a person as the perpetrator of terror no longer need to go pursuing an education in Afghanistan or in other places as a terror group. Due to the rapid development of information technology, this time a new generation of terrorists is quite intensively honed through social media by leveraging the internet. They use social media and communication features such as Telegram or Whatssapp.

This change of communication pattern also makes detection difficult. Terrorist groups also do not need to have a safe house or a fixed base camp because it can communicate anywhere. Bahrun Naim, one of the KN commanders routinely publishes manuals for making bombs, city guerrilla attacks, manuals of biological and chemical weapons, hacking, propaganda and recruitment strategies, to more effective tactical attacks. He shifts the writing patterns of books and pamphlets into writing on internet pages that are more accessible to many people. Some lonewolf attacks conducted in 2016 by ISIS in Southeast Asia were done through long distance guidance via social media and online directly from Syria. Thamrin Jakarta attack in January 2016 was among the actions that had a strong influence from the posts of the commander of the perpetrators. It was Bahrun Naim and Aman Abdurrahman, two ISIS Indonesia figures who influenced the perpetrators in carrying out their terrorist acts. The perpetrators are affected by Jihad thinking and carry out instructions published through online media and social media (Sholeh, 2017).

In addition, recruitment targets also began to change, the terrorist movement is now targeting young people and women to be "brides", or suicide bombers, in carrying out the action. This shows ISI targets and radicalism movements lead to younger groups, mainly by interaction through social media (El-Muhammady, 2016: 111). As for women, the election was to outwit law enforcement, as previously the terror perpetrators in Indonesia was always synonymous with men. Women are also considered more easily influenced, especially those who have problems in the family. Women are considered more militant in carrying out their actions, especially those who feel victimized in a conflict in the family or divorce. The recruitment pattern is the same, married then influenced. If previously these women only participated in religious studies and logistic preparation, now they are made the martyrs (Tempo, 2016).

According to KPAI, there are several recruitment modes commonly used by terrorists to launch the action. The first mode is marriage, such as the case of bombs in Bekasi-west Java in 2016. A man (MNS) married DYN after only getting to know her for 3 months through social media. The next mode is indoctrination through social media. The pattern, often chosen by terrorist network mentors, includes targeted teenagers. And what has recently happened is the pattern of child involvement, such as bombing in three Surabaya churches by one family. Dita Oepriyanto (47), his wife Puji Kuswati (43), and four children Yusuf Fadhil (18), Firman Halim (16), Fadhila Sari (12), Famela Rizqita (9) detonated a bomb in the Immaculate Sacred Church of St. Mary, Church Pantekosta Arjuna Street, and GKI on J1 Diponegoro, and caused 13 deaths and dozens of injuries.

There are five categories of terrorist network roles, namely executors, planners and field regulators, mentors or cadre seekers and nurseries, funders and sympathizers. In these five categories, at a certain stage, children engage in expression of hatred, such as hatred of 
government, of state apparatus, of the state system and of other disparate groups (Mediana, 2018).

\section{CONCLUSION}

The reduced power of ISIS in Iraq and Syria apparently did not immediately reduce the intensity of global terrorism, but instead became a threat for other countries with the return of the FTF militant ISIS that would be in action in their respective countries. The movement of terrorism itself is not new to Indonesia, prior to the Jama'ah Islamiyah ISIS, present as a terrorism organization dominated the action since the 2000-2013. There are several shifts in the pattern of movement of the JI with terrorism in the past few years that many claimed by Jama'ah Ansharut Even affiliated with ISIS. The first is a shift in tactics and movement patterns, namely abandonment of tanzhim or organizations as the container movement by starting the emergence of individual terrorism or Lone Wolf Terrorism. The second shift is the shift in motivation, which is affected by the difference in the purpose of organization and ideology. The ultimate goal of ISIS was the establishment of an Islamic State and declaring Abu Bakr al-baghdadi as the Caliph. While the JI, which is affiliated with Al-Qaida unequivocally states they have different motivation, which is attacking the West objects that are directly related to the conflict, such as the American Ambassador and the Philippines. Ideological differences pose a fundamental variation of motivation in terror act movements in Indonesia, in which the understanding of jihad, takfiri, al wala ' wal ' baro, hakimiyyah and unity among ISIS tends to be more extreme than JI. The third shift is a shift in the method of recruitment. Two changes occurred on the methods of recruitment of Jemaah Islamiyah terrorism movement and ISIS. The first was on recruitment and media, where the previous period recruitment activities were offline-centric, while now many use internet recruitment, the various social media platforms as well as Instant Messaging application like whatsapp and telegram. The radical thoughts of the leadership group copied from books to internet pages such as blogs are accessible to many people. Target recruitment also began to shift to young children and women to be "the bride" (martyrs), or suicide bombers, in carrying out the action. Of some of these indicators, the authors concluded that although the terror action along the 2014-2018 by JAD were affiliated with ISIS or sympathizers of ISIS, they are still relatively small in scale and number of victim. However, the consecutive acts of terror may pose a serious threat of the return of ISIS FTF milintantst to Indonesia.

\section{ACKNOWLEDGEMENT}

This research based on grant scheme of PITTA (Publikasi International Terindeks untuk Tugas Akhir) or also known as Indexed International Publications for Final Projects toward Universitas Indonesia students. Thank you to The Directorate of Research and Community Engagement of Universitas Indonesia (DRPM UI) for financial support

\section{REFERENCE}

[1]. Aziz Abdul, (2017) tirto.id: (Bandung Bombing and The strength of Lone Wolf Terrorism) Bom Bandung dan Menguatnya Lone Wolf Terorrism (online) Available from 
[2]. https://tirto.id/bom-bandung-dan-menguatnya-lone-wolf-terorrism-cjQW (Accessed 1 June 2018)

[3]. Bayoumi Yara, (2014) independent.co.uk: Isis urges more attacks on Western 'disbelievers' (Online) Available from

[4]. https://www.independent.co.uk/news/world/middle-east/isis-urges-more-attacks-onwestern-disbelievers-9749512.html (Accessed 20th May 2018)

[5]. Jones, Sidney (2016) (ISIS Threat in Indonesia) Ancaman ISIS di indonesia Sidney Jones (lecture) Available from https://www.youtube.com/watch?v=agJRGwTqoTU (Accessed 1st May 2018)

[6]. Mediana, Mesha, (2018) CNN: (Surabaya Bombing, using Children) Bom Surabaya 'Gandeng' Anak, KPAI Soroti Pola Terorisme, (online) Available from https:/www.cnnindonesia.com/gaya-hidup/20180515232519-284-298499/bomsurabaya-gandeng-anak-kpai-soroti-pola-terorisme (Accessed 1 st June 2018)

[7]. Reuters, (2016), Reuters: France sees sharp fall in number of citizens joining Islamic State. (Online) Available from: http://uk.reuters.com/article/uk-france-securitycazeneuve-idUKKCN11C2BN (Accessed 3rd June 2018)

[8]. Sholeh, Badrus. (2017) (From JI to ISIS: Strategic and Tactics Thought Terrorist Movement in Southeast Asia) Dari JI ke ISIS: Pemikiran Strategis dan Taktis Gerakan Terorisme di Asia

[9]. Tenggara. Journal of International Relationsal vol. 5 2nd edition, 211

[10]. Subhan Muhammad, (2016) (Shifting Orientation Islamic Terrorist Movement in Indonesia 2000-2015) PERGESERAN ORIENTASI GERAKAN TERORISME ISLAM DI INDONESIA (STUDI TERORISME TAHUN 2000-2015) Journal of International Relations, 2 (4), 59-67 (Online) Available from https://ejournal3.undip.ac.id/index.php/jihi/article/view/13409/12966 (Accessed 20th May 2018)

[11]. Tempo, (2016) Tempo: (Recrutment Strategy of Terrorist make a woman as a Martyr) Pola Rekrutmen Teroris Jadikan Perempuan sebagai 'Pengantin` (Online) Available from https://fokus.tempo.co/read/1001266/pola-rekrutmen-teroris-jadikan-perempuansebagai-pengantin (Accessed from 1 June 2018)

[12]. Waid abdul, (2017) (ISIS: Islamic Struggle and and The Declining of Political System, Comparison of ISIS Islamic Values with Present Political Systems) ISIS: PERJUANGAN ISLAM SEMU DAN KEMUNDURAN SISTEM POLITIK, Komparasi Nilai-Nilai Keislaman ISIS dengan Sistem Politik Kekinian (Online) Available from: http://ejournal.iain-tulungagung.ac.id/index.php/epis/article/view/72 (Accessed 3rd June 2018) 